\title{
Real-Time Ground-Water Data for the Nation
}

G round water is a critical natural resource used as a source of drinking water by more than 140 million people nationwide. Measurements of groundwater levels from wells are used to observe the effects of hydrologic stresses on an aquifer. These data are needed to monitor responses to climate and to ground-water development. Ground-water-level data are used to quantify aquifer recharge, as a calibration tool for ground-water models, and to support water-quality investigations.

Ground-water levels can be measured "continuously" or periodically. Periodic water-level measurements are those made manually at scheduled intervals, usually with a steel or electric tape. Continuous ground-water-level data are measured by an automatic sensing device, recorded by data loggers, and retrieved periodically from the field. The availability of these data lags current conditions by one to several months. During drought, when these data are in high demand, most areas of the Nation do not have timely data needed for effective ground-water management decisions. The technology now exists for continuous collection, transmittal, and processing of ground-water-level data to a central location for display of real-time ground-water conditions over the Internet when the data are needed most.

\section{“Real time and historical streamflow data.... are a resource to the nation and represent the type of data presentation we would like to see for groundwater data...."}

National Research Council, 2000, "Investigating Groundwater Systems on Regional and National Scales"

Real-time ground-water data are defined herein as data automatically collected, transmitted, and made available to the public at least once per day. These data can be transmitted by land-line telephone, cellular telephone, land-based radio frequency (RF) technology, satellite telemetry, or a combination of these technologies Satellite telemetry is the most common method used for real-time data transmission within the U.S. Geological Survey. Although some water-quality characteristics can be continuously monitored in wells, water levels are the most common data transmitted in real time by the USGS.

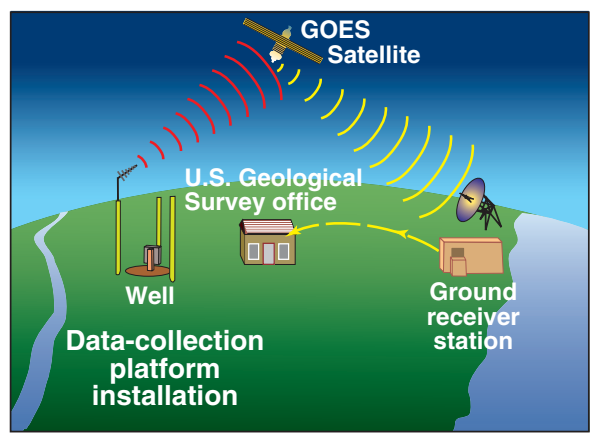

Real-time data collection and transmission system.

With this method, water-level data are recorded by a data-collection platform (DCP) and transmitted, often on a 4-hour schedule, by satellite telemetry to a USGS ground station. These data then are displayed over the Internet at http://water.usgs.gov/nwis/gw.

In October 2001, real-time groundwater data from at least 582 wells were being served from 35 States and Puerto Rico. The largest percentage ( 23 percent) of the wells were in Florida, and 6 States (Florida, Pennsylvania, Texas, North Carolina, Kansas, and Missouri) served nearly 75 percent of the wells with real-time instrumentation.

\section{Why Real-Time Data?}

Real-time ground-water data have many inherent advantages over data collected and distributed by traditional means. These advantages can be grouped into four categories: timeliness, data quality, data availability, and cost.

1. Timeliness - The most apparent benefit of real-time ground-water data is the ability to provide timely data for groundwater management. Most commonly, this is during drought conditions. Real-time ground-water data also can be used to monitor high water levels (ground-water flooding), to manage well fields, and to trigger ground-water sampling.

2. Data Quality - Real-time data collection and management improve the quality of continuous data. In contrast to traditional continuous data, which are retrieved on a monthly (or longer) schedule, real-time data are reviewed daily, and equipment malfunctions are identified quickly. Missing or poor quality data can be reduced substantially.
3. Data Availability - Real-time information promotes interest in ground-water data by bringing ground water to the public eye. Today more than ever, data users expect information to be available when and where they need it. With the USGS online National Water Information System (NWISWeb), ground-water levels can be served to the public almost immediately upon entry into the database. As timely, reliable data become the norm, more and more organizations and individuals will use the data, perhaps in unexpected ways.

4. Cost-The cost benefit of real-time data collection often is debated. Equipment and installation costs for real-time instrumentation are higher than for traditional methods. However, data-processing time and site visits can be significantly reduced. Real-time instrumentation is particularly beneficial at sites where access is difficult due to landowner restrictions or the remote nature of the site. One of the most overlooked aspects of real-time data is the decreased equipment costs and potential labor savings at closely spaced wells. Several nearby wells can be instrumented and transmitted using a single DCP. Some USGS offices take advantage of existing surface-water instrumentation to transmit ground-water data.

\section{Example Real-Time Applications Across the Nation}

Real-time ground-water monitoring is used effectively in many areas of the Nation.

\section{Florida}

Although Florida is blessed with abundant rainfall, large annual variations in precipitation result in water shortages, particularly during the dry winter months. Parts of Florida have been under drought conditions since October 1998, and 2000 was the driest year in at least 85 years in the 16-county Southwest Florida Water Management District. Because Florida State and local water managers have anticipated these climatic conditions, the USGS offices in Tampa and Miami maintain a network of more than 130 wells with real-time instrumentation. Data from 
these wells are used daily by the regulatory staff in Florida Water Management Districts to make decisions on water use (http://www.sfwmd.gov/). The South Florida Water Management District has chosen ground-water levels “...as the primary drought indicator because ground water responds more slowly to rainfall than surface waters...." Water-level data from these wells also have been used by the National Weather Service to characterize antecedent conditions for flood predictions.

\section{"toyed with the idea of going with a flood watch...but looked at the USGS ground water plots and these values were rel- atively low. Thus decided in not issuing a flood watch." \\ National Weather Service Area Forecast Discussion, Miami, Florida September 19, 2000}

\section{Pennsylvania}

In 1931, a statewide well network was established in Pennsylvania to monitor water-level fluctuations as a result of interest in ground-water-level declines resulting from the drought of 1930 . Today, this network consists of about 70 wells operated by USGS in cooperation with the Pennsylvania Department of Environmental Protection. The Commonwealth Drought Coordinator uses data from the wells when categorizing counties for a drought declaration. Presently, groundwater levels for nearly 70 network wells are transmitted by satellite telemetry and displayed on the USGS Web pages for Pennsylvania. Recently, the Pennsylvania Office has added 30-day moving average water levels and State-regulated drought levels to their data presentation (http://pa.water.usgs.gov/pa_duration.html).

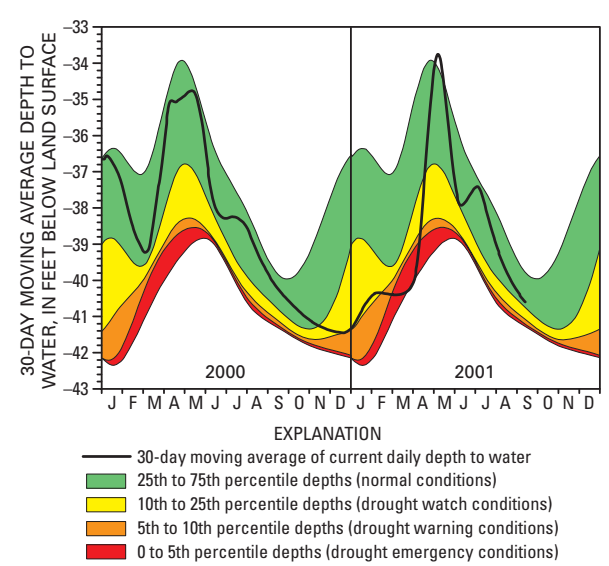

Hydrograph illustrating 30-day moving average of depth to water as compared to historical data, Well UN-51, Union County, Pennsylvania.

\section{Texas}

In response to the drought of 1996 , the Texas Legislature passed Texas Senate Bill 1 in 1997, a comprehensive waterplanning law dividing Texas into 16 waterplanning regions. This legislation requires regions to produce plans to address needs during periods when ground-water levels are 50- and 75-percent of normal. To help meet this requirement, about 45 wells within the State ground-water network are instrumented with satellite telemetry. The Texas Water Development Board and local governments use the real-time groundwater data to manage water during periods of drought.

Well "J17" near San Antonio is completed in the Edwards aquifer, the sole source of supply for the city. Water levels from this well are shown daily during weather reports on the local news stations. During November 2000, when water restrictions were prevalent in the San Antonio area, data from this well were served more than 11,000 times over the Internet.

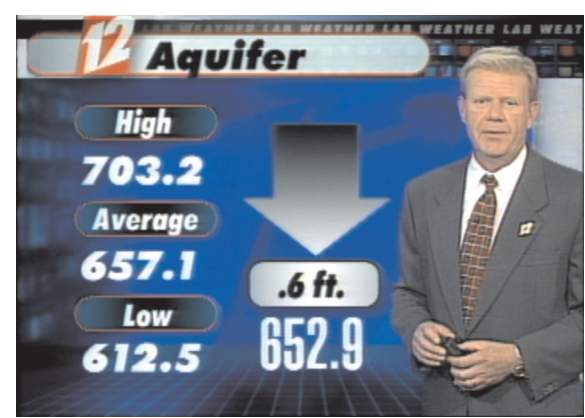

Daily water-level report during local weather forecast, KSAT Channel 12,

San Antonio, Texas (by permission).

\section{North Carolina}

Nutrient loading to estuaries is a critical concern in North Carolina. To help define nutrient sources, the USGS North Carolina Office has a program to sample discharge from tile drains on Coastal Plain farms. Real-time ground-water data from a nearby well are used to plan sampling events from the tile drains. Prior to the availability of real-time data, predicting when ground-water levels would be high enough to produce flows in the tile drains would have been difficult. The use of realtime data has eliminated field trips that were wasted because tile drains were dry.

\section{Kansas}

Water-level data have been collected since 1992 from wells and streams in the Kansas River Valley and upland areas of Fort Riley, Kansas. Because of the com-

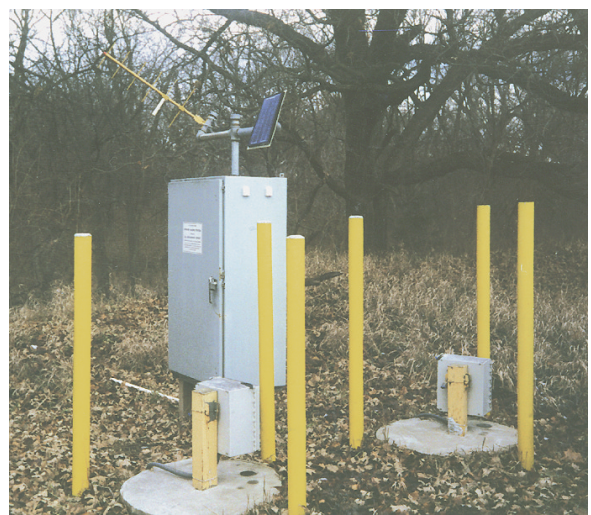

Multiple Sensor data-collection platform (DCP) installation in Kansas.

plex nature of the ground-water system, continuous water-level measurements are needed to evaluate ground-water flow and potential contaminant transport at Fort Riley. Approximately 30 DCP's have been installed to monitor ground-water levels at 56 wells. These data are used with surfacewater data to determine ground-water and surface-water interactions. When wells are too far from the surface-water gage for direct electrical connection of instrumentation, the USGS Kansas Office has installed RF systems to relay ground-water data to the DCP at the nearby gaging station for transmission to the office by telemetry. DCP's were selected for this investigation because they provide high-quality data and because of access restrictions at Fort Riley (Myers and others, 1999).

In conclusion, real-time ground-waterlevel data meet a critical need throughout the year under many circumstances, not just during drought. Real-time data applications allow effective aquifer management, produce high-quality data, and can be cost effective. As the availability and reliability of real-time ground-water data increase, so too will the value to scientists and the public alike.

\section{—William L. Cunningham}

\section{Reference}

Myers, N.C., Finnegan, P.J., and Breedlove, J.D., 1999, Analysis of water-level data and ground-water flow modeling at Fort Riley, Kansas: U.S. Geological Survey WaterResources Investigations Report 99-4115, $6 \mathrm{p}$.

For additional information about real-time ground-water data, please see http://water.usgs.gov/nwis/gw or contact:

Office of Ground Water

U.S. Geological Survey

411 National Center

12201 Sunrise Valley Drive

Reston, Virginia 20192

(703) 648-5001 